\title{
On Privileged Grounds: Sport, Law, and Agamben's State of Exception
}

\author{
Curtis A. Fogel ${ }^{1}$ \\ ${ }^{1}$ Criminology, Lakehead University Orillia, Ontario, Canada \\ Correspondence: Curtis A. Fogel, Criminology, Lakehead University Orillia, Ontario, Canada. E-mail: \\ cafogel@lakeheadu.ca
}

Received: June 5, 2014 Accepted: June 27, 2014 Online Published: August 25, 2014

doi:10.5539/jpl.v7n3p74 URL: http://dx.doi.org/10.5539/jpl.v7n3p74

\begin{abstract}
The central question examined in this paper is: does a state of legal exception exist in the context of sport and sporting competitions? That is, does the law of a particular land no longer apply on the fields of sport, much like it does not on many fields of war? An unobtrusive methodology, using legal case files as data, is used in this study to further examine this question. Four main areas of law are explored in particular including: 1) procedural law, 2) human rights law, 3) criminal law, and 4) EU law. The overall finding of this study is that no all-encompassing exception from the law exists in sport, but that sport does receive special considerations and privileges allowing for legal exceptions in many areas.
\end{abstract}

Keywords: sports law; criminal law; human rights

\section{Introduction}

Italian Philosopher Georgio Agamben refers to a "state of exception" as the suspension of laws in a given jurisdiction for a specified purpose, typically to maintain order and security in times of emergency such as wartime crisis. ${ }^{1}$ In France, this is often termed an état de siege; in England, it is termed Martial Law. This is not to say that no laws exist in a state of exception but rather, that the laws of a particular land are suspended and replaced with laws that are believed to more suitable to the particular conditions that are being faced. It is an unusual use of state power. A question that legal scholars and theorists of sport should ask is: does sport currently exist in a state of exception?

Many terms are commonly used to refer to the notion that sport might exist in a state of exception, such as Sporting Exemption, Sport Monopoly, Specialness of Sport, and Sport Autonomy. Another common term that has emerged more recently, largely from its direct mention in the White Paper on Sport $(2007)^{2}$, is the term Specificity of Sport. The basic notion behind these terms is the belief that (a) sport has an inherent uniqueness or specialness to it, and (b) that due to this uniqueness/specialness, sport should have exemptions from law.

There can be little debate that sport specificity has been established through various pieces of legislation and legal proceedings. The question must be: to what extent does the specificity of sport exist? Is it a full state of exception much like Agamben describes where sport administrators have totalitarian rule over matters that occur on fields of play, or is it much less autonomous than that? The overall finding of this study is that no all-encompassing exception from the law exists in sport, but that sport does receive special considerations and privileges allowing for legal exceptions in many areas.

\section{Clashes between Legislation, Law, and Sport}

The legislation of paramount importance to establishing the potential for sports exceptions from the law include, but are not limited to: 1) Declaration on Sport in the Treaty of Amsterdam (1997) ${ }^{3}$, 2) Helsinki Report on Sport $\left.(1999)^{4}, 3\right)$ Declaration on Sport in the Treaty of Nice $(2000)^{5}$, 4) White Paper on Sport $(2007)^{6}$, and 5) Treaty on

\footnotetext{
${ }^{1}$ Agamben, G. (2005). State of exception. Chicago, IL: University of Chicago Press. p. 1.

${ }^{2}$ Available online at: http://ec.europa.eu/sport/documents/wp_on_sport_en.pdf

${ }_{3}^{3}$ Available online at: http://eur-lex.europa.eu/en/treaties/dat/11997D/htm/11997D.html

${ }^{4}$ Available online at: http://eur-lex.europa.eu/LexUriServ/LexUriServ.do?uri=COM:1999:0644:FIN:EN:PDF

${ }_{5}^{5}$ Available online at: http://ec.europa.eu/competition/sectors/sports/policy.html

${ }^{6}$ See supra note 2 .
} 
the Functioning of the European Union (TFEU, 2009) ${ }^{7}$. A commonality in these documents is that a unique specialness of sport is recognized that opens the possibility for particular exceptions in the governance of sport, combined with an assertion that no absolute exceptions from law shall be granted. This assertion is summarized well in Article 165 of the TFEU, which states, "The Union shall contribute to the promotion of European sporting issues, while taking account of the specific nature of sport."

Through case law, the existence and limits of the exceptions in sport can be further identified and clarified. For the purposes of this paper, four areas of law will be explored, looking specifically at how questions of possible exceptions have been handled. The legal areas explored include: 1) Procedural Law, 2) Human Rights Law, 3) Criminal Law, and 4) EU Law.

\subsection{Sport and Procedural Law}

When appeals of disciplinary hearings in sport have reached English Courts, a repeated assertion has been made that for rulings of governing bodies of sport to stand, they must abide by the Principles of Natural Justice. As such, while governing bodies in sport might have some freedom to hold disciplinary hearings and govern themselves, it is not without legal oversight from the courts. As such, the procedures followed in sports governance and disciplinary proceedings do not exist in a state of exception.

Many cases have established and reinforced this precedent that governing bodies of sport must abide by these principles. For example, the judge presiding over Enderby Town FC v. The Football Association [1971] stated: "The long and the short of it is that if the court sees that a domestic tribunal is proposing to proceed in a manner contrary to natural justice, it can intervene to stop it." " Likewise, in Jones v. Welsh Rugby Football Union [1997], the judge stated:

It was an implied term of their contracts that in matters of discipline the Union would (a) properly apply its own rules and procedures in such a way as to produce a fair disciplinary process and (b) conduct those disciplinary procedures fairly, reasonably and in accordance with the rules of natural justice.

Similarly, in a Scottish case, a man named Yuill Irvine was suspended from a golf club for 12 months for wearing "ordinary" shoes on the course and other behaviours deemed unacceptable by the club management. He successfully challenged the ruling in court on the basis that the rules of natural justice were not followed and had his membership reinstated. ${ }^{9}$

In doping cases, it might be argued that some exemptions do exist in the way that governing bodies of sport handle such matters. CAS has established that the use of prohibited substances in sport is a strict liability offence. In a basic sense, this means that positive drug test results are an indication of guilt. It is no longer possible for athletes to argue on the basis of inadvertent drug use that they should not be held responsible for the presence of banned substances in their bodies. The most famous example of this predating the CAS ruling would be from the 1988 Olympics where Canadian sprinter Ben Johnson's initial defence was that he had unknowingly ingested steroids on route to winning the gold medal. While he was unsuccessful in his defence, American sprinter Carl Lewis used the same argument of inadvertent use and successfully had his silver medal upgraded to the gold that Johnson was required to give back. ${ }^{10}$

Such defences are no longer valid under current anti-doping standards. As such, some legal scholars have argued that the principles of natural justice and the right to a defence thereof have been ignored in sport and that the courts are allowing a special exception. However, disciplinary hearings still occur in cases of doping offences whereby the athlete could present a defence that challenges the merit of the test results. Furthermore, strict liability offences are not uncommon outside the context of sport, especially in relation to regulatory offences e.g. a speeding ticket.

\subsection{Sport and Human Rights Law}

The Human Rights Act (1998) makes it unlawful for a public authority to act in a way that is incompatible with the European Convention on Human Rights and Fundamental Freedoms. However, the courts in England have ruled that sports governing bodies are not a "public authority" and therefore sport is exempt from this body of law. It can be argued that sport is a public authority as it is typically funded by public money and the decisions made in sport can have a large public impact; however, the English courts have maintained that it is a private

\footnotetext{
${ }^{7}$ Available online at: http://eur-lex.europa.eu/LexUriServ/LexUriServ.do?uri=OJ:C:2010:083:0047:0200:en:PDF

${ }^{8}$ Enderby Town FC v. The Football Association [1971] 1 All ER 215.

${ }^{9}$ Irvine v. Royal Burgess Golfing Society of Edinburgh [2004] SCLR 386.

${ }^{10}$ Johnson, W. O., \& Moore, K. (1988). The loser. Sports Illustrated.
} 
entity.

Exemption from the Human Rights Act does not mean, however, that sports organizations are free to discriminate against individuals on protected grounds in the Convention as they like. As an employer, sports organizations must adhere to the Equity Act. ${ }^{11}$ They cannot discriminate against their employees, including athletes, nor in providing goods and services to the public. For example, in Sterling v. Leeds Rugby League Cup [2001] a rugby league player was successful in in filing a claim of racial discrimination. ${ }^{12}$

In contrast to racial discrimination, some exemptions on the basis of sex and gender do appear to exist in the governance of sport. Section 195(3) of the Equity Act provides an allowance for sex discrimination in sports of:

a competitive nature in circumstances in which the physical strength, stamina or physique of average persons of one sex would put them at a disadvantage compared to average persons of the other sex as competitors in events involving the activity.

Likewise, according to Bradford (2005), "all anti-discrimination legislation in Australia provides an exception that allows sporting organisations to exclude participants on the basis of their sex where strength, stamina and physique of the athletes are relevant." 13

In Bennett v. Football Association and Nottinghamshire Football Association (unreported decision on July 28, 1998) a ruling that the prevented an 11-year old schoolgirl from playing football with boys was upheld. Likewise, in Taylor v. Moorabbin Saints the courts ruled that a 13-year old girl could not be excluded from competing against boys of her age in Australian Rules Football, but that 14 and 15 -year old girls could be excluded. ${ }^{14}$ The arguments presented were that girls will be at high risk to get hurt competing against boys who are physically stronger, and that the inclusion of girls in boy's sport would lessen the competitive nature of the sport. Via these outdated, stereotypical notions of sex and gender an exception for sport and discrimination has been established.

Exceptions from Freedom of Religion rights also appear to exist in the context of sport. The Amateur Boxing Association of England (ABAE) requires that all boxers be clean-shaven for safety reasons. ${ }^{15}$ Boxing officials have made the case that facial hair has the risk of scratching the eye of opponents when competitors become tied up, that beards rubbing on an opponent's face can further open up gashes, and that it is difficult for medical staff to locate and treat open wounds within facial hair. In many religious faiths, beards hold significant meaning, e.g. Sikhism. As such, requiring boxers to be clean-shaven could be considered a violation on Freedom of Religion. The ABAE contends, however, that their rule is proportionate and justified and at present sport appears to be exempted on these grounds for such rules.

\subsection{Sport and Criminal Law}

One area of law where public criticism is often waged against judiciaries for their failure to uphold laws is in relation to violence in sport, and assault laws in particular. For example, in the sport of Canadian football, which is not played by kicking a spherical ball (what Canadians call soccer) but instead involves constant tackles and violent hits, there has not been a single case where a professional athlete has been criminally charged for violence on the field. ${ }^{16}$ This is a sport where catastrophic injuries are commonplace, yet the courts have allowed Canadian football to self-govern violence.

In contrast, however, Canadian ice hockey has not been afforded the same exception. In a select few cases, Canadian hockey players have appeared in Canadian courts. Of those, even fewer have resulted in successful convictions by the prosecution. A primary reason for this lack of successful convictions of assault in Canadian ice hockey in the legal notion of volenti non fit injuria, or "to a willing person, injury is not done."17 That is, there is a basic understanding that if an act of violence in sport is consented to, that no crime has occurred.

The consent defence does not, however, give sport an absolute exception from assault law. In R. v. McSorley $(2000)^{18}$, professional hockey player Marty McSorley violently struck his stick against the head of an opposing player named Donald Brashear, who he had engaged in consensual fighting with earlier in the game, and was

\footnotetext{
${ }^{11}$ Available online at: http://www.legislation.gov.uk/ukpga/2010/15/contents.

${ }_{12}$ Sterling v. Leeds Rugby League Cup [2001] ISLR 201.

${ }_{13}$ Bradford, M. (2005). Sport, gender and law. International Sports Law Journal, 1(2), 78-83.

${ }^{14}$ Taylor v. Moorabbin Saints Football League and Football Victoria [2004] VCAT 158.

${ }^{15}$ Cottrell, S. (2010). Freedom of religion and rules of safety. World Sports Law Report, 8(2), 12-16.

${ }^{16}$ Fogel, C. (2013). Game-day gangsters: Crime and deviance in Canadian football. Edmonton, AB: Athabasca University Press.

${ }^{17}$ Corbett, R., Findlay, H., \& Lech, D. (2008). Legal issues in sport. Toronto: Edmond. p. 28.

${ }^{18}$ R. v. McSorley [2000] B.C.J. 1993.
} 
charged with assault with a deadly weapon. Four years later, another professional hockey player named Todd Bertuzzi appeared in Canadian courts for an incidence of violence in professional ice hockey. ${ }^{19}$ In this incident, Todd Bertuzzi struck another player, Steve Moore, in the back of the head with his gloved fist, resulting in two broken vertebra and brain injuries that subsequently ended his hockey career. Bertuzzi was given a conditional discharge on the grounds that he serves 80 hours of community service.

Non-players can also be held liable for injuries in sport. For example, in Smolden v. Whitworth $(1997)^{20}$ and Vowles v. Evans $(2003)^{21}$ the referees of two separate rugby matches were both held liable for the injuries that players sustained as a result of undue care by the referees in keeping control over the game. In a Canadian case, a high school football player sought damages from a Board of Education because of a broken neck he sustained during play that he argued was a result from improper coaching ${ }^{22}$. Similarly, in Dunn v. University of Ottawa $(1995)^{23}$, a football player successfully sought damages from the coach of the opposing team for failing to adequately control his players and coaching staff, which ultimately led to his injury.

In England, an important legal precedent for sports violence was established in 1981, though it was not in the context of sport. In this particular case, two young men aged 17 and 18 engaged in a fist fight that led to injuries. Though it was consented to, the fighting was deemed to not be in public interest. As such, the boys were not given a legal exemption from assault law. However, it is through this provision that violence in sport can continue without interference from the courts providing it can be shown to be in the public interest. As such, a public interest exception appears to exist in relation to sports violence in England, which allows for the continuation of violent sports like mixed-martial arts, rugby, and boxing.

\subsection{Sport and EU Law}

The area of law that appears to clash with sports governance most frequently in recent years is the broad area of EU Law. Where EU law clashes with sport governance is typically in the establishment of sport rules that typically, though not exclusively, i) provide unfair financial advantage, ii) restrict freedom of movement of people, or iii) restrict freedom to provide services.

For the 1998 World Cup football tournament hosted in and won by France, approximately 750,000 tickets were sold strictly to people who had a postal code in France. Locals bought the tickets and then sold them at inflated prices to foreign visitors, giving citizens of France a competitive economic advantage. French football officials argued that the sale to local residents was done as a precaution to limit conflict and violence during matches. The courts ruled that there was no reasonable sport-specific justification for the postal code rule, and that since it had clear economic implications it was in violation of EU Law. ${ }^{24}$ The courts ensured that a rule of a governing body of sport could not be used to financial benefit the citizens of one nation over others, without a valid sport-related justification.

Many cases have come before the courts on the question of sports rules restricting the freedom of movement of people/workers: Bosman ${ }^{25}$, Walgrave and Koch ${ }^{26}$, Dona and Mantero ${ }^{27}$, Deliège ${ }^{28}$, Lehtonen $^{29}$, Kolpak $^{30}$, and Simutenkov ${ }^{31}$ to name a few. In a basic sense, the result of these cases has been to establish that governing bodies of sport cannot create rules that prohibit the free movement of athletes across national borders, with exceptions granted only if there is a justified sporting reason such as establishing competitions between nations like the Olympics or FIFA World Cup.

Athletes have also argued that anti-doping policies violate their right to freedom of providing services, as positive tests are typically accompanied by mandatory suspensions that restrict athletes from participating in

\footnotetext{
${ }^{19}$ R. v. Bertuzzi [2004] B.C.J. 2692.

${ }^{20}$ Smolden v. Whitworth [1997] E.L.R. 115.

${ }^{21}$ Vowles v. Evans [2003] W.L.R. 1607.

${ }^{22}$ Thomas (Next friend of) v. Hamilton Board of Education [1994] O.J. 2444.

${ }^{23}$ Dunn v. University of Ottawa [1995] O.J. 2856.

${ }^{24}$ Decision 2000/12 1998 Football World Cup OJ 2000 L5/55.

${ }^{25}$ Union Royale Belge des Sociétés de Football Association ASBL v Jean-Marc Bosman [1995] C-415/93.

${ }^{26}$ Walgrave \& Koch v. Association Union Cycliste Internationale [1974] Case 36/74 ECR.

${ }^{27}$ Dona v Mantero [1976] ECR 1333, [1976] 2 CMLR 578, ECJ.

${ }^{28}$ Deliège v Ligue francophone de judo et disciplines associées ASBL, Ligue belge de judo ASBL, Union européenne de judo [2000] C-51/96.

${ }^{29}$ Lehtonen and others v. Federation Royale Belge de Societies de basket- ball [1996] ASBL C-176.

${ }^{30}$ Deutscher Handballbund v Kolpak [2003] ECR I4135.

${ }^{31}$ Igor Simutenkov v Abogado de Estad, Real Fedracion Espanola de Futbol and Ministero Fiscal [2005] ECJ 12.
} 
their livelihood. In $E d w a r d s^{32}$, the presiding judge ruled that prohibiting athletes from taking banned substances was a rule of a purely sporting nature with no economic purpose. Likewise, in Meca-Medina ${ }^{33}$, anti-doping rules were again upheld on the basis that they are purely sporting rules with no economic purpose. Furthermore, anti-doping regulations were perceived by the courts to fulfill important function of competitive balance in sport and safeguarding the health of athletes.

\section{Concluding Remarks}

Some very specific sporting exceptions do and should exist. Sport has certain unique properties that justify some exceptions from law, such as the need to maintain competitive balance between teams, to ensure safety of participants, and to maintain integrity of the game. In general, the specificity of sport allows for legal exceptions providing there are no unfair economic implications of sporting rules and governance, that rules are purely in the interest of sport, and that any sporting exemptions are made in public interest.

No state of exception from sport exists in the form that Agamben describes. By the very fact that clashes between legislation, law, and sport continue to occur it can be seen that no pure state of exception from the laws of the land exist. If such an exception did exist, there would be no clashing. Exceptions, are, however, made on a case-by-case basis at the ongoing and ever-changing discretion of the courts. The sporting exceptions that do exist are not absolute or unconditional. The courts have, to date, been very careful to not give governing bodies in sport an open exception from treaties, laws, and legislation. While the courts do grant governing bodies of sport many freedoms to govern themselves alongside certain specific exceptions, these freedoms are not without constraint of the law and judicial oversight. Given the increasing public and economic role of sport in society, it stands to reason that such a state of exception should not be permitted in the interests of public good.

\section{Copyrights}

Copyright for this article is retained by the author(s), with first publication rights granted to the journal.

This is an open-access article distributed under the terms and conditions of the Creative Commons Attribution license (http://creativecommons.org/licenses/by/3.0/).

${ }^{32}$ Edwards $v$ BAF and IAAF [1998] 2 CMLR 363.

${ }^{33}$ Meca-Medina v. EC Commission [2006] 5CMLR 18. 